\title{
Effect of cimetidine on the human lower oesophageal sphincter
}

\author{
D. H. OSBORNE, J. LENNON, M. HENDERSON, G. LIDGARD, \\ R. CREEL, ${ }^{1}$ AND D. C. CARTER
}

From the Department of Clinical Surgery, Edinburgh University, the Wolfson Gastrointestinal Laboratories, Western General Hospital, Edinburgh, and the Regional Hormone Laboratory, Edinburgh

SUMMARY Lower oesophageal sphincter pressures in healthy volunteers were measured by a rapid pull-through technique during intravenous infusion of the histamine $\mathrm{H}_{2}$-receptor antagonist, cimetidine. No consistent effects on sphincter pressure were observed which are liable to be of clinical importance. Serum gastrin concentrations during cimetidine infusion were measured by radioimmunoassay and showed no significant variation. In a further series of experiments, the response of the lower oesophageal sphincter to intravenous bolus injection of pentagastrin was measured before and during cimetidine infusion. Cimetidine infusion had no significant effect on the sphincter response to pentagastrin.

The lower oesophageal sphincter (LOS) is a zone of high pressure which can be distinguished from the body of the oesophagus in that it is forcefully closed at rest but relaxes to offer little resistance to flow during swallowing. The force of closure varies slowly and irregularly under physiological conditions and is attributable to an intrinsic property of the muscle in this zone, and to neural and possibly hormonal control mechanisms. It has been suggested that the sphincter can be influenced by a number of stimuli including the gastrointestinal hormones gastrin and secretin (Giles et al., 1969; Castell and Harris, 1970; Cohen and Lipshutz, 1971), and pharmacological stimuli such as metoclopramide (Heitmann and Möller, 1970; Stanciu and Bennet, 1973; Cohen et al., 1976), bethanecol (Farrell et al., 1973), and prostaglandins (Dilawari et al., 1973).

The histamine $\mathrm{H}_{2}$-receptor antagonist, metiamide, is a potent inhibitor of gastric secretion which has been shown to encourage healing of duodenal ulcers in preliminary clinical trials (Multicentre Trial, 1975), although its use has been curtailed by toxic effects on the bone marrow. Metiamide has recently been superseded by cimetidine, which appears free from bone marrow toxicity, is a potent inhibitor of gastric secretion (Burland et al., 1975; Pounder et al., 1975; Carter et al., 1976) and is currently under-

Received for publication 12 August 1976 going clinical evaluation in the peptic ulcer diathesis.

Cohen and Snape (1975) have recently postulated that there are both excitatory and inhibitory histamine receptors in the lower oesophageal sphincter of the opossum. These authors have shown that metiamide produced a dose related rise in LOS pressure and also augmented the response of the sphincter to synthetic gastrin I. In vitro studies have shown that, while metiamide alone did not affect muscle tension, it still augmented the response to histamine, suggesting that $\mathrm{H}_{2}$ receptors are inhibitory at this site.

The present studies were undertaken to assess whether cimetidine has any effect on LOS pressure in man which might prove of clinical significance and to determine its effect on the response of the LOS to pentagastrin.

\section{Methods}

\section{TECHNIQUE OF MEASUREMENT OF LOS} PRESSURE

LOS pressure was measured using a rapid pullthrough technique based on the method initially described by Waldeck (1972) and later modified by Lennon and his colleagues (1975). A single lumen polyvinyl tube $120 \mathrm{~cm}$ long, of external diameter $3 \mathrm{~mm}$ and internal diameter $2 \mathrm{~mm}$, was occluded $6 \mathrm{~cm}$ from its tip, and two $1 \mathrm{~mm}$ lateral openings 
made immediately proximal to the point of occlusion. During pressure recording the tube was perfused at a rate of $6.0 \mathrm{ml} / \mathrm{min}$ with water from four greased glass $50 \mathrm{ml}$ syringes in a Harvard constant infusion pump. The delivery from this pump when tested on the bench over 50 deliveries was $6.0 \pm$ SD $0.1 \mathrm{ml} / \mathrm{min}$ (range 5.8 to $6.2 \mathrm{ml} / \mathrm{min}$ ). Pressure within the system was transmitted by an open threeway tap to a pressure transducer (Bell and Howell L221) connected to an M-19 Devices multichannel recorder to give a permanent record. The system was calibrated before each test by reference to a manometric column of water. The characteristics of the system at the perfusion rate employed were such that digital occlusion of the recording orifices gave a pressure rise of $70 \mathrm{~mm} \mathrm{Hg} / \mathrm{s}$.

All recordings were made with the subjects supine. The tube was passed through the mouth until the lateral openings were within the stomach. A preliminary assessment of the gastro-oesophageal junction was obtained by withdrawing the tube in $1 \mathrm{~cm}$ steps to define the high pressure zone. All subsequent measurements of LOS pressure were made using the rapid pull-through technique in which the tube was withdrawn at a constant rate of $0.9 \mathrm{~cm} / \mathrm{s}$. The rate of withdrawal was found to be constant under simulated conditions with weights ranging from 10 to $100 \mathrm{~g}$ attached to the distal end of the tube. During the 10-15 seconds required for each pull-through, the subject cooperated by not swallowing and suspending respiration after normal inspiration or expiration. The tube was then reintroduced over the 10 to $15 \mathrm{~cm}$ it had been withdrawn, the whole process of LOS pressure measurement taking less than 30 seconds.

By convention, LOS pressure was expressed as the peak height of the profile relative to intragastric pressure, measured in $\mathrm{mmHg}$.

\section{GROUPS OF EXPERIMENTS}

The total number of studies performed was 24 . There were three exclusions on the grounds of the subject failing to tolerate the tube for the duration of the test, otherwise all records have been included leaving 21 tests in seven subjects.

All studies were performed in healthy male volunteers (aged 25-35 years) free from known upper gastrointestinal pathology, and giving informed consent to all investigations. All studies were carried out after a 12 hour overnight fast.

GROUP 1: EFFECT OF INTRAVENOUS SALINE INFUSION ON LOS PRESSURE

Five studies were performed, one in each of five subjects. LOS pressure was recorded at 10 minute intervals with two recordings in inspiration and two in expiration. After an initial 40 minute basal period, normal saline was infused intravenously from a Palmer pump at a constant rate of $10.6 \mathrm{ml} / \mathrm{h}$, and LOS pressure recorded at 10 minute intervals for the duration of a 90 minute infusion.

GROUP 2: EFFECT OF INTRAVENOUS CIMETIDINE INFUSION ON LOS PRESSURE Six studies were performed, one in each of six subjects. LOS pressure was recorded at 15 minute intervals with two recordings in inspiration and two in expiration, during a 45 minute basal period, a 90 minute intravenous infusion of cimetidine, and for 30 minutes thereafter. Cimetidine was delivered by a Palmer pump at $100 \mathrm{mg} / \mathrm{h}$, diluted in normal saline to administer a volume of $10.6 \mathrm{ml} / \mathrm{h}$. Eight millilitres of venous blood were withdrawn at 15 minute intervals from a separate indwelling cannula for serum gastrin assay. The clotted blood was centrifuged within 30 minutes and the serum separated and stored at $-20^{\circ} \mathrm{C}$ until all samples were assayed in a single batch. Gastrin was measured by radioimmunoassay using Amberlite resin CG-4B to separate bound from free gastrin. The antiserum had an association constant of $4.7 \times 10^{11} 1 / \mathrm{mol}$ for human gastrin I. Cross-reaction with cholecystokinin and pentagastrin was $1 \times 10^{4}$ on a molar basis, and $60 \%$ for big gastrin on a molar basis. Porcine gastrin $\mathrm{I}-\mathrm{I}_{125}$ was used as the tracer, and calibration of human gastrin I was in terms of MRC Standard $68 / 539$ relative potency $1: 1$. The within-assay cuefficient of variation was $7.0 \%$ and the betweenassay coefficient of variation $8.0 \%$. The assay sensitivity was $10 \mathrm{ng} / \mathrm{l}$.

GROUP 3: EFFECT OF INTRAVENOUS CIMETIDINE INFUSION ON LOS RESPONSE TO PENTAGASTRIN

Seven studies were performed in four subjects. LOS pressure was recorded every two minutes alternately in inspiration and expiration over a 16 minute basal period. An intravenous bolus of pentagastrin $(0.5 \mu \mathrm{g} / \mathrm{kg})$ was given over one minute, and pressure recorded at one minute intervals over the next 10 minutes. A 60 minute infusion of cimetidine $(100 \mathrm{mg} / \mathrm{h}$ as in group 2) was then started and, after the initial 34 minutes of this infusion, the sequence of pre-pentagastrin pressure recording, pentagastrin bolus, and post-pentagastrin recording was repeated.

Control tests were carried out in three of these subjects by omitting cimetidine from the saline vehicle of infusion.

STATISTICAL ANALYSIS

The statistical significance of the results has been assessed using a $t$ test for the analysis of paired data. 


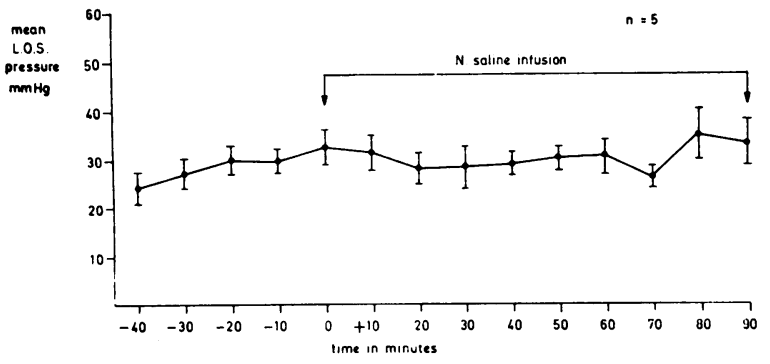

(a)

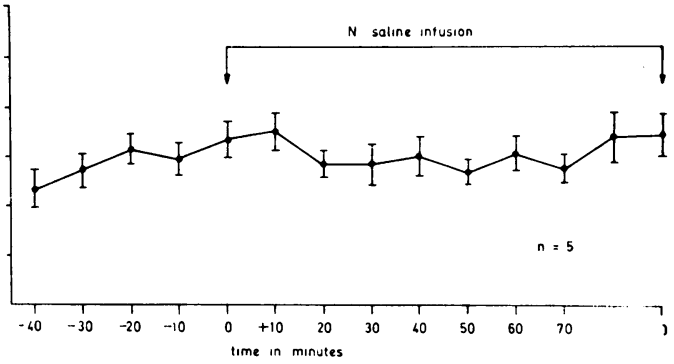

(b)

Fig. 1 a. Effect of infusion of normal saline on mean expiratory LOS pressure (mean $\pm S E M)$. $b$. Effect of infusion of normal saline on mean inspiratory LOS pressure (mean $\pm S E M)$.

Results

\section{GROUP 1}

The effect of saline infusion on LOS pressure in five subjects is shown in Fig. 1. The mean inspiratory pressure during saline infusion ranged between 27 and $36 \mathrm{~mm} \mathrm{Hg}$, while the mean expiratory pressure ranged from 26 to $36 \mathrm{~mm} \mathrm{Hg}$. Mean LOS pressure during the saline infusion did not differ significantly from the mean pressures during the basal period.

\section{GROUP 2}

The effect of cimetidine infusion on LOS pressure in six subjects is shown in Fig. 2. It is apparent that there is no pressure rise, the mean pressure tending to fall as the cimetidine infusion progresses. The mean inspiratory pressures are unstable during the basal period and, although there is a pressure reduction during cimetidine infusion, we are reluctant to make statistical analysis of this data. The mean expiratory pressures are lowest after 75 minutes of cimetidine, and this reduction is statistically significant when compared with basal pressures $(P<0.05)$. Four of these subjects have control data available from saline infusion studies. Statistical analysis showed no difference in sphincter pressure between the cimetidine and control infusions.

The serum gastrin response during cimetidine infusion is shown in Fig. 3. The mean serum gastrin level tends to rise as the infusion progresses, but at no stage does this reach statistical significance when compared with basal values.

\section{GROUP 3}

The effect of cimetidine infusion on mean LOS pressure in response to pentagastrin in seven studies is shown in Fig. 4. The initial peak shows the response of the sphincter to pentagastrin alone, with a rapid rise from basal pressures of between 23 and $26 \mathrm{~mm} \mathrm{Hg}$ to a peak of $62 \mathrm{~mm} \mathrm{Hg}$ at two minutes, with a rapid fall thereafter towards basal levels. The second peak shows the sphincter response to the same dose of pentagastrin during cimetidine infusion. The mean LOS pressure before the second bolus of pentagastrin varied between 23 and $29 \mathrm{~mm} \mathrm{Hg}$ whereas the peak response was $49 \mathrm{~mm} \mathrm{Hg}$ at two minutes, with a rapid return thereafter towards basal pressure. The difference between the two responses is not statistically significant $(P>$ 0.05). In control tests using saline rather than

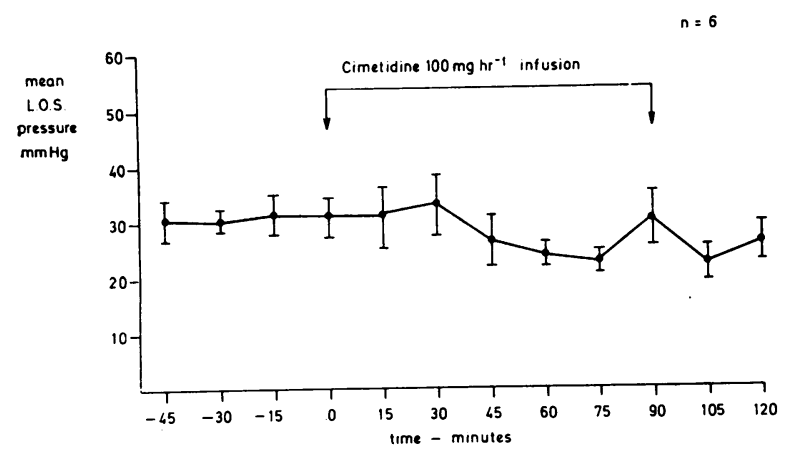

(a)

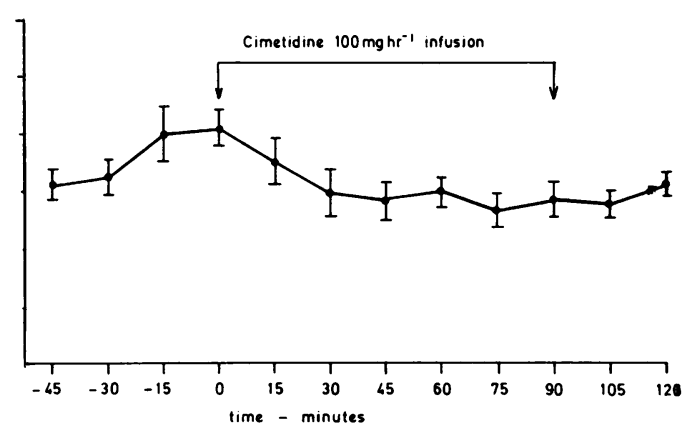

(b)

Fig. 2 a. Effect of cimetidine infusion on mean expiratory LOS pressure (mean $\pm S E M)$. b. Effect of cimetidine infusion on mean inspiratory LOS pressure (mean $\pm S E M)$. 


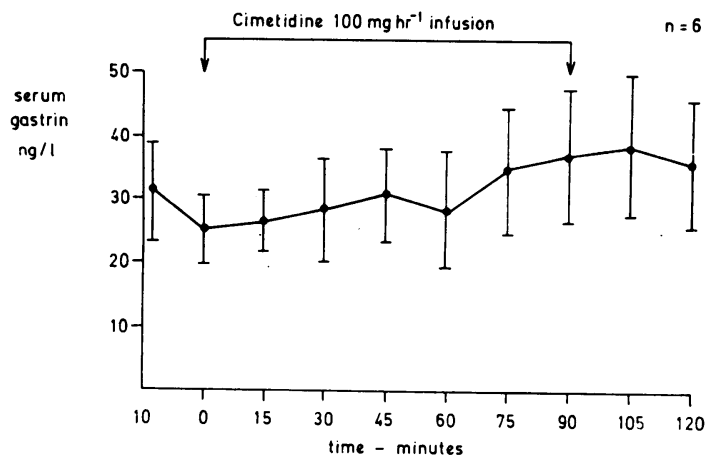

Fig. 3 Effect of cimetidine infusion on mean serum gastrin concentration (mean $\pm S D$ ).

cimetidine infusion, a similar pattern of response to pentagastrin was observed. The mean peak LOS response to pentagastrin before saline infusion was $54 \mathrm{~mm} \mathrm{Hg}$, whereas during saline infusion the response to pentagastrin was $41 \mathrm{~mm} \mathrm{Hg}$. The difference between the two responses is not statistically significant.

\section{Discussion}

The type of rapid pull-through technique used in the present study has been shown to minimise observer scoring error, avoid recording artefact due to respiratory movement of the LOS relative to the pressure recording orifice, and to give more reproducible values for LOS pressure than conventional station pull-through techniques (Dodds et al., 1975). Pump compliance was reduced in the present study by use of greased syringes, while catheter compliance was minimised by using a thick-walled minimally elastic tube with an internal diameter of only $2 \mathrm{~mm}$.
At the rate of infusion used in the present study our system is capable of measuring a pressure rise rate of $70 \mathrm{~mm} \mathrm{Hg} / \mathrm{s}$ and, although greater rise rates may be needed to monitor peristaltic pressure changes in the body of the oesophagus (Stef et al., 1974; Dodds et al., 1976), we feel that this rise rate is adequate for the needs of the present experiment and have avoided increasing the rate of infusion.

Cimetidine in the dose used in the present experiments has been shown to achieve blood levels of $1.26 \mu \mathrm{g} / \mathrm{ml} 60$ minutes after starting infusion (Carter et al., 1976), this level being above the concentration required for $50 \%$ inhibition of gastric acid secretion (Burland et al., 1975).

In the six subjects studied, this dose of cimetidine had no consistent effects on LOS and, although mean expiratory pressure was significantly below basal values after 75 minutes of cimetidine, the absolute fall was only $8.5 \mathrm{~mm} \mathrm{Hg}$ and by 90 minutes mean LOS pressure had returned to basal values (Fig. 2).. We feel that these changes are more likely to be due to non-specific variation in sphincter pressure than to a specific effect of cimetidine. This contention is supported by the fact that variations in mean expiratory LOS pressure of a similar magnitude were observed during control saline infusion (Fig. 1), and that no comparable changes in mean LOS pressure were observed when pressures were recorded during suspended inspiration (Fig. 2). The absence of any marked or consistent effects of cimetidine in the present studies suggests that the drug is unlikely to have any actions on the LOS which will be of importance in clinical practice.

In common with other histamine $\mathbf{H}_{2}$-receptor antagonists, cimetidine does not inhibit acid output by a primary effect on the rate of secretion of gastrin (Mainardi et al., 1974; Pounder et al., 1976). Nevertheless, changes in intragastric $\mathrm{pH}$ could have

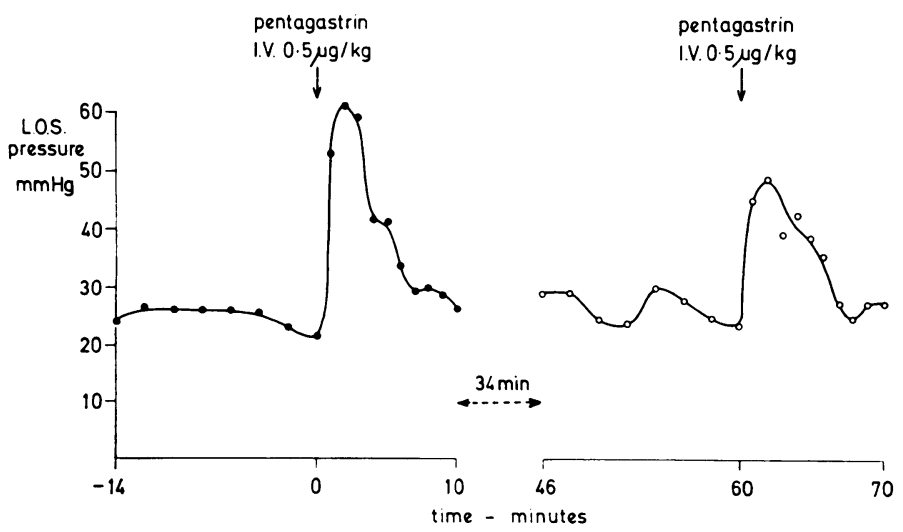

Fig. 4 Effect of cimetidine infusion on the mean $L O S$ response to intravenous pentagastrin. Cimetidine infusion (100 $\mathrm{mg} / \mathrm{hr}$ ) was started 10 minutes after the first bolus of pentagastrin, and continued for 60 minutes thereafter. 
secondary effects on gastrin release, and gastrin concentrations were measured during cimetidine infusion in the present studies. The role of gastrin as a physiological determinant of LOS pressure is now in debate, and the recent studies of Dent and Hansky (1976) and our own unpublished data, have failed to confirm earlier suggestions that gastrin is involved in LOS control (Giles et al., 1969; Castell and Harris, 1970; McCall et al., 1975). In any event, mean serum gastrin concentrations did not show any statistically significant variation from basal values (Fig. 3) and gastrin can probably be discounted as a factor affecting LOS response in the present experiments.

The failure of cimetidine to have a consistent effect on LOS pressure is at variance with the results of Cohen and Snape (1975) with the $\mathrm{H}_{2}$-receptor antagonist metiamide. It may be that species difference between man and opossum is responsible for the discrepancy, but it is still possible that higher doses of cimetidine given on a long-term basis could produce clinically significant changes in man. This problem is currently under review.

Similarly, our results with combinations of cimetidine and pentagastrin are not in keeping with the results of Cohen and Snape (1975). The dose of pentagastrin used in our experiments $(0.5 \mu \mathrm{g} / \mathrm{kg})$ was selected as a submaximal dose on the basis of preliminary pilot studies to determine the response of the LOS to bolus injections of pentagastrin in the dose range $0.0625-1 \cdot 0 \mu \mathrm{g} / \mathrm{kg}$. Admittedly our data are in no way comparable with the formal in vitro dose-response studies with opossum LOS, but we have failed to show any evidence of potentiation between pentagastrin and cimetidine in man with the doses under study. In fact, the mean sphincter pressure response to pentagastrin was actually reduced when pentagastrin was injected during cimetidine infusion (Fig. 4).

Grossman and Konturek (1974) have suggested that the ability of histamine $\mathbf{H}_{2}$-receptor antagonists to inhibit gastric secretion induced by pentagastrin could be explained by interaction between gastrin and histamine receptors at the parietal cell. Comparable interaction at the LOS would enable cimetidine to antagonise the sphincter response to gastrin and would be in keeping with our data. However, this assumes that the human LOS contains both histamine and gastrin receptors, and that histamine $\mathrm{H}_{2}$-receptors are excitatory at the LOS as well as at the parietal cell. These assumptions are unwarranted as the existence of physiological gastrin receptors at the LOS is in debate, while Cohen and Snape postulate that $\mathrm{H}_{2}$-receptors at the LOS are inhibitory rather than excitatory. The situation requires clarification in man for it is possible that further studies with the LOS would throw light on the nature of interaction between gastrin and histamine receptors at the parietal cell.

The authors wish to thank the volunteers taking part in these studies and Miss Elizabeth Drummond for help in the performance of the experiments. We are grateful to Professor A. P. M. Forrest for his continued support and encouragement and to Mrs B. Beck for secretarial assistance. During the performance of these studies, Mr D. C. Carter was supported by the Wellcome Trust.

\section{References}

Burland, W. L., Duncan, W. A. M., Hesselbo, T., Mills, J. G., Sharpe, P. C., Haggie, S. J., and Wyllie, J. H. (1975). Pharmacological evaluation of cimetidine, a new histamine $\mathrm{H}_{2}$ receptor antagonist, in healthy man. British Journal of Clinical Pharmacology, 2, 481-486.

Carter, D. C., Forrest, J. A. H., Logan, R., Ansell, I., Lidgard, G., and Heading, R. C. (1976). The effect of cimetidine on insulin induced gastric acid secretion in man. Scandinavian Journal of Gastroenterology, 11, 565-570.

Castell, D. O., and Harris, L. D. (1970). Hormonal control of gastro-esophageal sphincter strength. New England Journal of Medicine, 282, 886-889.

Cohen, S., and Lipshutz, W. (1971). Hormonal regulation of human lower esophageal sphincter competence: interaction of gastrin and secretin. Journal of Clinical Investigation, 50, 449-454.

Cohen, S., Morris, D. W., Schoen, H. J., DiMarina, A. J. (1976). The effect of oral and intravenous metoclopramide on human lower esophageal sphincter pressure. Gastroenterology, 70, 484-487.

Cohen, S., and Snape, W. J. Jr (1975). Action of metiamide on the lower esophageal sphincter. Gastroenterology, 69, 911-919.

Dent, J., and Hansky, J. (1976). Relationship of serum gastrin response to lower oesophageal sphincter pressure. Gut, 17, 144-146.

Dilawari, J. B., Newman, A., Poleo, J., and Misiewicz, J. J. (1975). Response of the human cardiac sphincter to circulating prostaglandins $F_{22}$ and $E_{2}$ and to antiinflammatory drugs. Gut, 16, 137-143.

Dodds, W. J., Hogan, W. J., Stef, J. J., Miller, W. N., Lydon, S. B., and Arndorfer, R. C. (1975). A rapid pullthrough technique for measuring lower esophageal sphincter pressure. Gastroenterology, 68, 437-443.

Dodds, W. J., Stef, J. J., and Hogan, W. J. (1976). Factors determining pressure measurement accuracy by intraluminal esophageal manometry. Gastroenterology, 70, 117-123.

Farrell, R. L., Roling, G. T., and Castell, D. O. (1973). Stimulation of the incompetent lower esophageal sphincter, a possible advance in therapy of heartburn. American Journal of Digestive Diseases, 18, 646-650.

Giles, G. R., Mason, M. C., Humphries, C., and Clark, C. G. (1969). Action of gastrin on the lower oesophageal sphincter in man. Gut, 10, 730-734.

Grossman, M. I., and Konturek, S. J. (1974). Inhibition of acid secretion in dog by metiamide, a histamine antagonist acting on $\mathrm{H}_{2}$ receptors. Gastroenterology, 66, 517-521.

Heitmann, P., and Möller, N. (1970). The effect of metoclopramide on the gastroesophageal junctional zone and the distal oesophagus in man. Scandinavian Journal of Gastroenterology, 5, 621-625. 
Lennon, J., Copeland, W., Lidgard, G., Eastwood, M., and Sircus, W. (1975). Studies of the oesophageal antireflux mechanism using a modified rapid withdrawal manometric method and combined fluoroscopy. Gut, 16, 482. (Abstract.)

McCall, I. W., Harvey, R. F., Owens, C. J., and Clendinnen, B. G. (1975). . Relationship between changes in plasma gastrin and lower oesophageal sphincter pressure after meals. British Journal of Surgery, 62, 15-18.

Mainardi, M., Maxwell, V., Sturdevant, R. A. L., and Isenberg, J. I. (1974). Metiamide, an $\mathrm{H}_{2}$ receptor blocker, as inhibitor of basal and meal-stimulated gastric acid secretion in patients with duodenal ulcer. New England Journal of Medicine, 291, 373-376.

Multicentre Trial (1975). Treatment of duodenal ulcer by metiamide. Lancet, 2, 779-781.

Pounder, R. E., Williams, J. G., Milton-Thompson, G. J., and Misiewicz, J. J. (1975). 24-hour control of intragastric acidity by cimetidine in duodenal ulcer patients. Lancet, 2, 1069-1072.

Pounder, R. E., Williams, J. G., Russell, R. C. G., MiltonThompson, G. J., and Misiewicz, J. J. (1976). Inhibition of food-stimulated gastric acid secretion by cimetidine. Gut, 17, 161-168.

Stanciu, C., and Bennett, J. R. (1973). Metoclopramide in gastro-oesophageal reflux. Gut, 14, 275-279.

Stef, J. J., Dodds, W. J., Hogan, W. J., Linehan, J. H., and Stewart, E. T. (1974). Intraluminal esophageal manometry: an analysis of variables affecting recording fidelity of peristaltic pressures. Gastroenterology, 67, 221-230.

Waldeck, F. (1972). A new procedure for functional analysis of the lower esophageal sphincter (LES). Pflügers Archives, 335, 74-84. 